\title{
6. Transmedia Storytelling
}

\author{
New Practices and Audiences
}

Melanie Schiller

\section{Prologue}

Stories in popular culture such as StAR WARs, GAME of Thrones, HARry PotTER, or superhero sagas in the Marvel universe, are examples of stories which are increasingly told across a wide range of media, from novels and books to (animated) television series and feature films, jigsaw puzzles and computer games, online blogs, vlogs, webisodes, social media, and so-called mobisodes (short episodes made specifically for viewing on mobile phones). Another famous example is the Wachowskis' The MATRIX (1999-2005), where key pieces of information are conveyed across three action films, a series of animated shorts, two collections of comic book stories, and several video games. In the case of THE MATRIX, there is no single urtext from which one can gain all the information needed to comprehend the story's universe (Jenkins 2007). For such new forms of storytelling associated with media convergence and expanding across multiple media platforms, Jenkins (2006) coined the (umbrella) term transmedia storytelling. The term refers to:

a process where integral elements of a fiction get dispersed systematically across multiple delivery channels for the purpose of creating a unified and coordinated entertainment experience. Ideally, each medium makes its own unique contribution to the unfolding of the story. (Jenkins 2007, n.p.)

From the start, the phenomenon was clearly interesting for the industry, as shown by THE MATRIX. The entertainment industry was finding new ways to appeal to audiences, by merging media with marketing and entertainment strategies to appeal to young audiences in ways that had not been available to them in the predigital era. Nevertheless, there is more to this than marketing alone. The range of phenomena referred to by the term "transmedia storytelling" involves many different aspects, including new forms of storytelling and complex narratives; a new cultural context in which social media, connectivity, fan cultures, and online-information exchange play a big role, as do the use of marketing strategies and appropriate business models to address audiences in the world of digital connectivity. Smart 
technologies are abundantly available to facilitate such processes; and new legal frameworks can help frame and support them (Gambarato 2015, 81).

However strongly new practices of storytelling across media are linked with the media entertainment industries' commercial interests in promoting entertainment franchises, it can hardly be denied that transmedia storytelling is also driven by users' increasing desire for transmedia experiences, as emphasized by recent debates (Clash of Realities 2015, 99). The phenomenon fits into the broader context of a growing popularity of user-generated content and fan productions. The culture of media convergence is typically marked by a flow of content across multiple media platforms, the cooperation between multiple media industries, and the migratory behavior of media audiences "who will go almost anywhere in search of the kinds of entertainment experiences they want" (Jenkins 2006, 2). According to Jenkins, this new culture marks a cultural shift from a spectatorial culture of "passive" media consumption to a more active, participatory culture, as fans and consumers are encouraged to seek out new information themselves, to make their own connections among dispersed media content, and to participate actively in the creation and circulation of new stories and content $(2006,3)$.

It seems clear that the suggested shift from "passive" consumer to "active" participant presupposes a collaborative relationship of some sort between professional authors / industry-embedded producers and the consumer base of amateurs. The term coined for this is "collaborative authorship." The new practice of transmedia storytelling (Bernardo 2011) assumes new forms of cooperation between:

- different media industries, such as film, gaming, and publishing;

- different professional roles, such as screen-writers, comic-book writers, animators, and programmers;

- different artists shaping the story; and

- a collaborative relationship with the consumer base of participating amateurs.

To explain how the new practices work, Jenkins discusses stories, such as HEROES (2006-2010) or LOST (2004-2010), which have spread from television series to comics, the web, computer and alternative-reality games (also part of the entertainment industry), and the like. In the process, they acquire new consumers as they unfold, allowing the most dedicated fans to take it one step further (Jenkins 2010, 948). These fans are described by Jenkins and others as actively participating in the process: they translate their interests in the stories and the franchise into a range of media messages, 
from concordances and Wikipedia entries, fan fiction, and fan videos to fan films, "cosplay," and game mods. ${ }^{1}$ Such participatory fan practices inevitably extend the story world in new directions. Thus, both commercial and grassroots expansions of narrative universes may contribute to a new mode of transmedia storytelling which can best be understood as both a top-down corporate process and a bottom-up consumer-driven one (Jenkins and Deuze 2008, 6).

\section{Adaptation, Remediation, Transmedia, and Storytelling in the Stricter Sense}

For a further understanding of these new practices of storytelling across media, it is important to distinguish between media adaptations or remediations - like the film version of a novel - and transmedia storytelling in the stricter sense. While the first points to the unidirectional movement from one medium to another, the latter refers to a much broader expansion of narrative structure through storytelling activities in a range of different semiotic systems (verbal, iconic, behavioral) and historical media practices (cinema, comics, television, video games), all of which contribute to the construction of the overall transmedia story world (Scolari 2009).

There are also other terms, often referred to alongside transmedia storytelling, which must be kept separate, as they refer to phenomena other than storytelling, such as cross-media communication. In general, both terms refer to media production that takes place through different display technologies and media platforms (such as social networking, YouTube). However, cross-media communication is a broader, more generic term that includes the whole process of communication and interactivity (Mungioli 2011, 128; Gambarato 2013, 83). In the case of transmedia storytelling, the emphasis is strictly on narrative, and each medium involved in the storytelling practice is assumed to do what it does best (Jenkins 2006, 96). This implies that the story told by a comic book will be different from that told on television as part of a TV series, or the story world presented in a video game.

A story may well move across media, as the study by Marie-Laure Ryan and Jan-Noël Thon, Storyworlds across Media (2014), suggests. In light of these new developments in storytelling, they plead for new narrative theories, and a Media-Conscious Narratology, as the subtitle of their study indicates. As narrative experts, Ryan and Thon were originally interested in stories and storytelling strategies found mainly in literature. More recently, however, they have come to address phenomena such as stories moving across media, 
acknowledging that new practices of storytelling have evolved and that a story may be introduced in a film, expanded through a television series, explored through (graphic) novels and comics, and experienced through theme parks, game play, interactive websites, and fan fora. Jenkins argued that for a transmedia story world to develop in this way, each of these media platforms needs to be sufficiently self-contained to enable autonomous consumption: the user of the media content need not have read the comic to enjoy the film or play the game (Jenkins 2006, 98).

Although it may be argued that transmedia storytelling reflects the economics of media consolidation or "media synergy," the phenomenon should not be conflated with general transmedia extensions of franchise branding. Transmedia storytelling, even in the stricter sense, may still include some narrative extensions of a new blockbuster movie through the release of prequel comic book issues, or expanded backstories in a video game. Nevertheless, the phenomenon cannot be reduced to mere franchise branding and exploitation, as in the production of toys, merchandise and the release of the original soundtrack on promotional websites. In the reality of marketing, these cross-media activities often go together and ideally even create some synergy. Clearly, however, the analysis of branding and marketing strategies invites a different analytical approach than the narrative analyses of story worlds across media. Whereas the latter may benefit from narrative analyses of expanding story worlds and puzzling story twists, as Ryan, Thon and others (cognitivists among them) offer, Harvard business professor, Anita Elberse, has argued in her study on blockbusters for an analysis of marketing strategies of the film / entertainment industry in line with social impulses and behavior of audiences (Elberse 2013). Elberse acknowledges that people, by their very nature, are social beings and find value in reading the same books, watching the same television shows, and visiting the same movies in the cinema as others do. Social beings like to take part in social activities in which they know others are taking part. In other words, transmedia storytelling practices may go well with marketing strategies of the industry aiming at creating blockbusters. Once a certain story (a film, book, certain character, or star) is popular and has been widely discussed in the media, audiences have much more reason to become part of the intrinsically social phenomena of reading/seeing/discussing this popular object of interest. With the "blockbuster" strategies adopted by the industry to promote one movie on a massive scale rather than many movies in a moderate or small way, the "winner takes all" effect in the world of big budget movies, together with big budget marketing, ensures that audiences are pulled in and become 
participants in these captivating story worlds which are celebrated across media (Elberse 2013).

\section{Transmedia as a Buzzword}

Despite the growing prominence in media studies of transmedia as a buzzword (Ryan 2015) and the fact that transmedia storytelling may be a new concept, any thoughtful study of contemporary transmedia must acknowledge that it is not a new phenomenon, unique to the digital age, as several authors have noted (Scolari, Bertetti, and Freeman 2014). MarieLaure Ryan recalls that story worlds involving multiple authors and artists interpreting and representing such worlds in many media already existed long before digital media and the social web - indeed it may be traced back at least to classical Greece and perhaps even before (Ryan 2013). One need only think of pictures dramatizing biblical scenes, or iconic nineteenth-century characters such as Frankenstein or Sherlock Holmes whose narrative scope transcends any single medium, as noted by Jason Mittell. Alternatively, we may think of one of US television's first hits, DRAGNET, which spanned multiple media, having started as a radio program. The popular TV series spawned many novels; a feature film; a hit record for its theme song; tie-in toys such as a board game, a police badge, and a whistle; and even a television reboot of the 1950s original in the late $1960 \mathrm{~s}$ (Mittell 2015). Other famous examples are STAR TreK and Doctor WHO, or even popular narratives as early as the 1930s, such as MICKEY MousE or BATMAN, all of which made their appearance in different media (comics, pulp magazines, radio, etc.) (Scolari et al. 2014). Moreover, fan fiction is far from a new phenomenon, having existed before the digital revolution, as Ryan observes, while acknowledging that the phenomenon has since exploded across the Internet, making it possible for fans to share their creations with countless other fans across the globe (Ryan 2013, 10; Lindgren Leavenworth 2015; Thomas 2011).

A second point of criticism addresses the celebratory tone of some studies, starting with Jenkins's widely cited 2006 book, which celebrated the new era of transmedia storytelling in terms of a participatory culture that replaced passive consumers with active audiences. This binary opposition was criticized as anachronistic, making a claim that was already commonplace within poststructuralism, after Roland Barthes's celebration of "the Death of the Author" in the late 1960s (Barthes 1967); and Stuart Hall, as the founder of Cultural Studies, who emphasized the active audience 
in his influential "encoding-decoding" model in the 1970s (Hall 1973). The question then must be: to what extent is the phenomenon genuinely new?

\section{What Is New and Different about Transmedia Storytelling?}

The phenomenon is not entirely new, but rooted in much older practices, as several authors have argued, also stating that the proliferation of digital forms has led to a marked increase in transmedia storytelling practices and techniques (Mittell 2015; Gambarato 2015). Drawing on these commentators, we might summarize what is new and different about transmedia storytelling - and what narrative analyses we may want to focus on in future research - as follows.

It involves creating a new corpus of extensive stories that move beyond traditional storytelling and demand new terms of user participation as well as analysis. These stories manifest themselves less as singular plots, and may seem to readers and viewers more like architecturally narrative universes, inhabited by multiple characters, and articulating complex temporalities and contradictory perspectives. As transmedia stories can be told from different points of view, with shifting narrators and changes in focalization, these narrative universes are typically open-ended. As a result of fan-fiction and user participation, the temporal composition of these narratives becomes increasingly complex, since by their very nature, transmedia stories unfold in different sequences and across different timeframes for each audience member (Kustritz 2017). Additionally, as Kustritz observes, fan narratives not only include events which are out of sequence, but may also contain numerous alternate interpretations and versions of the same events.

Transmedia narratives, as they move through different media, problematize notions of authorship: these narrative universes do so not only by expanding across multiple media, which necessitates collective authorship, but also by allowing and actively encouraging audience participation. As a result, the borders between text, paratext, and fan-fiction become increasingly blurred. While it is relatively easy to identify the author of a novel (disregarding the editors and others who may have had an invisible hand in its composition), it is more difficult to single out one creative participant as the author of an entity as economically and culturally all-encompassing as Harry Potter, notes James Russell (2012). The \#BlackHermione fan fiction, for instance, which identifies Harry Potter's friend, Hermione, as a Person of Color, has now been incorporated into the "official" Harry Potter universe when the character (as an adult) was played by Swaziland-born 
actress, Noma Dumezweni, in the 2016 London stage production of Harry Potter and the Cursed Child - a prequel to the original Harry Potter novels. Therefore, the questions are now: Who determines a character's personality traits? Who makes the rules in the fictional universe? And who decides what "really" happened? (Kustritz 2014) Increasing dependence on (fan) participation obviously challenges traditional notions of authorship, and one may wonder whether there are forms which challenge and indeed worry the entertainment industry focused on keeping control of its market position. In light of this, it is interesting to observe that franchises attempt to retain traditional markers of authority such as authorship. In the "Wizarding World" of Harry Potter, the official website Pottermore, in an interesting balancing act, seeks to reinvent the brand and prolong engagement with its fan base, while simultaneously reinforcing J.K. Rowling as the central authorial figure of the story world (Brummitt 2016).

Transmedia storytelling as such depends on audience participation and therefore grants increased agency to fan cultures. Increasingly, fans are agents in the creation and negotiation of the meaning-making of (popular) cultural texts. An advantage of this, often mentioned in debates, is that it can lead to more diverse representations in popular culture. Jenkins celebrated this shift in narrative authority, perhaps prematurely, in his books and many articles as "we take control of the media." However, it is fair to note that the emergence, however slow, of different marginalized perspectives in mainstream popular culture is becoming a force to be reckoned with. Fan-cultural production and fan-consumers are no longer considered eccentric irritants, but rather loyal and devoted consumers (Hills 2002). The STAR WARS fans, who have been putting pressure on the entertainment industry to provide a different, more diverse set of characters, and who have shown mounting impatience with the industry's slow process of diversification of the franchise's universe, are a good example of this. As a result, the transnational casting of THE ForCE AwAKENs (2015) and RoguE ONE (2016) finally portrayed strong female characters and characters of color, although Disney was still reluctant to fully embrace this diversification in its marketing strategies (Guynes and Hassler-Forest 2018). The progress of this trend might be measured in terms of such recent films as WONDER WOMAN (2017) and BLACK PANTHER (2018), which surely reflect the importance of fan cultures today.

The new emphasis on collaborative authorship leads to yet another important element of transmedia narratives: their dependence on the participation of audiences reemphasizes the fundamentally social function of stories, as Walter Benjamin (2006) outlined in his 1936 essay. Today, 
this is echoed by Nuno Bernardo (2016), an expert in story design for a multiplatform audience, who defines storytelling as bringing individuals together by revealing some truth about the world around them.

Finally, realizing how essential stories are for our social positioning in the world, transmedia storytelling may also create new opportunities in fields beyond fictional entertainment. These new practices of storytelling seem to offer, and indeed scholars are exploring, the potential of transmedia storytelling for expanding learning opportunities in higher education (Fleming 2011; Pence 2011; Kalogeras 2014), nonfictional storytelling in journalism (Moloney 2011; Veglis 2012; Pernía Peñalver and Semova 2014), and in politics and activism (Brough and Shresthova 2012). For Jenkins, a veteran of earlier phases of studying popular media, it is clear that we need shared stories in order to imagine what a better world may look like and to work toward its achievement (Guynes and Hassler-Forest 2018).

\section{Epilogue}

Transmedia storytelling is a relatively new phenomenon and, in terms of production and analysis, is still in its infancy. Theoretical and analytical considerations around the development of transmedia projects are evolving, but remain relatively open in terms of results (Gambarato 2015). Broadcasters and the industry are in the process of finding the right narratives (Bernardo 2018) and the right role for them to play, while scholars have embarked on the definition of key terms and discussion of research goals and methods of analysis. Additionally, the practice of storytelling itself is far from fully developed and, as Propp said of his work on folktales in 1928, analyzing the structure of such hitherto disregarded material will increase the possibilities for creating new stories (Scolari 2009).

Media developer, Brian Clark, maintains that there have been no great transmedia successes yet, at least partly because most transmedia stories were not conceived as such from the outset, but became transmedial (Ryan 2013). The future should bring new kinds of stories. Creating coherent complex transmedia narratives requires a degree of storytelling control that the current system of television production seems unable to meet fully. Taking into account that transmedia stories propose new institutional as well as new narrative models (Scolari 2009), future development will need teams that are able to successfully manage such integrated narratives (Mittell 2015). It will also be interesting to see the impact of further technological innovations - such as Google Glasses, or $4 \mathrm{~K}, 8 \mathrm{~K}$, and live cinema (Coppola 
2017) - offering potentially greater immersion, multiple timelines, and interactive storytelling (Freeman 2017).

To respond to the growing influence of fans, the industry will have to produce an enhanced diversity of characters and story world representations, as is already happening to a limited extent. Further research also needs to address the dynamic interplay between marketing-driven transmedia storytelling on the one hand, and the home-made contributions of audiences on the other. Lastly, new narrative models and concepts for collective forms of authorship still need to be developed, to address the convergence of the traditionally separate roles of authors, industry, and consumers.

\section{Notes}

1. Cosplay or costume play refers to participants wearing costumes and fashion accessories to represent a specific character. Game mods are modifications of an existing game to enhance its appeal or complexity.

\section{References and Further Reading}

Benjamin, Walter. 2006 [1936]. "The Storyteller." In The Novel: An Anthology of Criticism and Theory 1900-2000, edited by Dorothy J. Hale. Malden, MA: Blackwell Publishing.

Barthes, Roland. 1977 [1967]. "The Death of the Author." In Image, Music, Text, 142-148. New York: Hill \& Wang.

Bernardo, Nuno. 2011. The Producer's Guide to Transmedia: How to Develop, Fund, Produce and Distribute Compelling Stories across Multiple Platforms. London: beActive Books.

—. 2016. "Story Design for a Multi-Platform Audience." Nuno Bernardo (blog), February 19, 2016. http://nunobernardo.com/story-design-for-multiplatform-audience/.

Brough, Melissa M., and Sangita Shresthova. 2012. "Fandom Meets Activism: Rethinking Civic and Political Participation." Transformative Works and Cultures 10.

Brummitt, Cassie. 2016. "Pottermore: Transmedia Storytelling and Authorship in Harry Potter." The Midwest Quarterly 58:112-132.

Clash of Realities, ed. 2017. Clash of Realities 2015/16: On the Art, Technology and Theory of Digital Games. Proceedings of the 6 th and 7 th Conference. Bielefeld: transcript Verlag.

Coppola, Francis Ford. 2017. Live Cinema and Its Techniques. New York and London: Liveright.

Elberse, Anita. 2013. Blockbusters. Hit-Making, Risk-Taking, and the Big Business of Entertainment. New York: Henry Holt \& Company.

Fleming, Laura. 2011. "Pedagogical Considerations of the Transmedia Mythology." EdTech Insight: Transmedia and Education.

-. 2013. "Expanding Learning Opportunities with Transmedia Practices: Inanimate Alice as an Exemplar." Journal of Media Literacy Education 5, no. 2: 370-377.

Foucault, Michel. 1984 [1969]. "What Is an Author?" In The Foucault Reader, edited by Paul Rabinow, 299-314. New York: Pantheon Books. 
Freeman, Matthew. 2017. Historicising Transmedia Storytelling: Early Twentieth-Century Transmedia. London: Routledge.

Gambarato, R.R. 2015. "Transmedia Project Design: Theoretical and Analytical Considerations." Baltic Screen Media Review 1: 80-100. https://doi.org/10.1515/bsmr-2015-0006.

Guynes, Sean, and Dan Hassler-Forest, eds. 2018. Star Wars and the History of Transmedia Storytelling, Transmedia. Vol. 3. Amsterdam: Amsterdam University Press.

Hall, Stuart. 1973. Encoding and Decoding in the Television Discourse. Birmingham: Centre for Cultural Studies, University of Birmingham.

Hills, Matt. 2002. Fan Cultures. New York: Psychology Press.

Jenkins, Henry. 2006. Convergence Culture: Where Old and New Media Collide. New York: New York University Press.

—. 2007. "Transmedia Storytelling 101." Henry Jenkins. Confessions of an Aca-Fan (blog), March 21, 2007.http://henryjenkins.org/blog/2007/03/transmedia_storytelling_101.html.

- 2010. "Transmedia Storytelling and Entertainment: An Annotated Syllabus." Continuum 24: 943-958. https://doi.org/10.1080/10304312.2010.510599.

—. 2018. "Transmedia Storytelling." MIT Technology Review. https://www.technologyreview. com/s/40176o/transmedia-storytelling/.

Jenkins, Henry, and Mark Deuze. 2008. “Editorial: Convergence Culture." Convergence 14: 5-12. https://doi.org/10.1177/1354856507084415.

Kalogeras, Stavroula. 2014. Transmedia Storytelling and the New Era of Media Convergence in Higher Education. London: Springer.

Kustritz, A.M. 2014. "Seriality and Transmediality in the Fan Multiverse - Flexible and Multiple Narrative Structures in Fan Fiction, Art, and Vids." TV/Series 6: 225-261.

- 2017. "Interactivité, resémantisation, et plaisirs de la primauté ontologique - les œuvres de fans comme centre du récit." Revue Française des Sciences de l'Information et de la Communication 10.

Lindgren Leavenworth, Maria. 2015. "The Paratext of Fan Fiction." Narrative 23, no. 1: 40-6o.

Mittell, Jason, ed. 2015. "Transmedia Storytelling." In Complex TV, The Poetics of Contemporary Television Storytelling, 292-318. New York: New York University Press. http://www.jstor.org/ stable/j.ctt15r3zwk.13.

Moloney, Kevin T. 2011. Porting Transmedia Storytelling to Journalism. Denver: University of Denver.

Mungioli, M.C. 2011. "Narratives, Languages and Media in the Context of Interactive Digital Technologies: Interview with Carlos A. Scolari.” MATRIZes: Revista do Programa de PósGraduação em Ciências da Comunicação da Universidade de São Paulo 4, no. 2: 127-136.

Nuno Bernardo. 2018. http://nunobernardo.com/author/admin/.

Pence, Harry E. 2011. “Teaching with Transmedia." Journal of Educational Technology Systems 40, no.2: 131-140.

Pernía Peñalver, Noé Orlando, and Dimitrina Semova. 2014. “Crisis Política y Narrativas Transmedia En Las Protestas de 2014 En Venezuela / Political Crisis and Transmedia Storytelling in the 2014 Protests in Venezuela." Revista Mediterránea de Comunicación 7: 163-177.

Russell, James. 2012. "Authorship, Commerce, and Harry Potter." In A Companion to Literature, Film, and Adaptation, edited by Deborah Cartmell, 391-407. Oxford and Malden, MA: John Wiley \& Sons. Ltd. https://doi.org/10.1002/9781118312032.ch22.

Ryan, Marie-Laure. 2013. "Transmedial Storytelling and Transfictionality." Poetics Today 34, no. 3: 361-388.

-.2015. "Transmedia Storytelling: Industry Buzzword or New Narrative Experience?" Storyworlds: A Journal of Narrative Studies 7: 1-19. https://doi.org/10.5250/storyworlds.7.2.0001. 
Ryan, Marie-Laure, and Jan-Noël Thon. 2014. Storyworlds across Media: Toward a Media-Conscious Narratology. Lincoln and London: University of Nebraska Press. https://muse.jhu.edu/ book/31010.

Scolari, Carlos Alberto. 20o9. "Transmedia Storytelling: Implicit Consumers, Narrative Worlds, and Branding in Contemporary Media Production." International Journal of Communication 3: 586-6o6.

Scolari, C., P. Bertetti, and M. Freeman. 2014. Transmedia Archaeology: Storytelling in the Borderlines of Science Fiction, Comics and Pulp Magazines. London: Springer.

Thomas, Bronwen. 2011. "What Is Fanfiction and Why Are People Saying Such Nice Things about It?" Storyworlds 3: 1-24.

Veglis, Andreas. 2012. "From Cross Media to Transmedia Reporting in Newspaper Articles." Publishing Research Quarterly 28, no. 4: 313-324. 
